This article was downloaded by: [University of Strathclyde]

On: 06 February 2015, At: 08:03

Publisher: Routledge

Informa Ltd Registered in England and Wales Registered Number: 1072954

Registered office: Mortimer House, 37-41 Mortimer Street, London W1T 3J H, UK

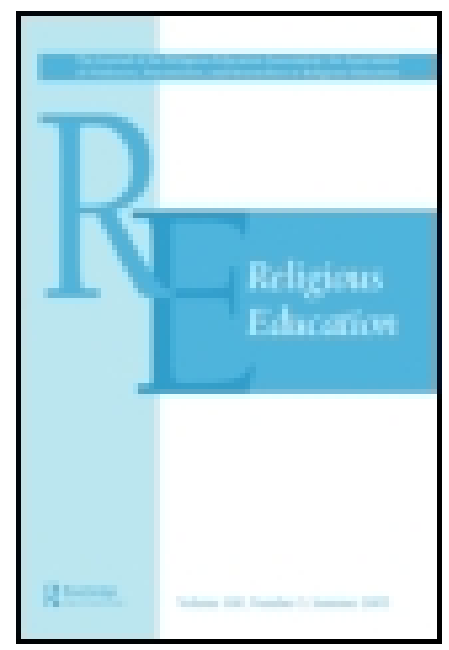

Religious Education: The official journal of the Religious Education Association

Publication details, including instructions for authors and subscription information:

http:// www.tandfonline.com/loi/ urea20

\title{
A New Type of Sunday School Lessons
}

Ira M. Price Ph. D.

Published online: $10 \mathrm{~J} \mathrm{ul} 2006$.

To cite this article: Ira M. Price Ph.D. (1921) A New Type of Sunday School Lessons, Religious Education: The official journal of the Religious Education Association, 16:1, 44-44, DOI: 10.1080/0034408210160109

To link to this article: http:// dx.doi.org/ 10.1080/0034408210160109

\section{PLEASE SCROLL DOWN FOR ARTICLE}

Taylor \& Francis makes every effort to ensure the accuracy of all the information (the "Content") contained in the publications on our platform. However, Taylor \& Francis, our agents, and our licensors make no representations or warranties whatsoever as to the accuracy, completeness, or suitability for any purpose of the Content. Any opinions and views expressed in this publication are the opinions and views of the authors, and are not the views of or endorsed by Taylor \& Francis. The accuracy of the Content should not be relied upon and should be independently verified with primary sources of information. Taylor and Francis shall not be liable for any losses, actions, claims, proceedings, demands, costs, expenses, damages, and other liabilities whatsoever or howsoever caused arising directly or indirectly in connection with, in relation to or arising out of the use of the Content.

This article may be used for research, teaching, and private study purposes. Any substantial or systematic reproduction, redistribution, reselling, loan, sub-licensing, systematic supply, or distribution in any form to anyone is expressly forbidden.

Terms \& Conditions of access and use can be found at http://www.tandfonline.com/ page/terms-and-conditions 


\title{
A New Type of Sunday School Lessons
}

\author{
Ira M. Price, Ph.D.*
}

The Sunday School Lesson Committee has two types of lessons on its docket. (1) The Improved Uniform Series, an adaptation of the old Uniform series for the use of the Sunday school made up of from one to four departments, viz: (a) Primary, (b) Junior, (c) Intermediate and Senior, (d) Young People and Adults. This brand of lesson was worked out and has been in vogue since 1918, the first year of the new eight-year cycle. The final revision of 1923 is just off the press, and the second proof of the 1924 list has just been sent out for criticism. (2) The International Graded Series, graded by years from ages four to twenty, completed several years ago. This series is more generally used in schools that are highly graded and well supplied with trained teachers.

At the last semi-annual meeting of the Lesson Committee-now consisting of forty-two persons-at Atlantic City, December 29, 30, 1920, a Commission of Seven of which Prof. L. A. Weigle of Yale University is Chairman, made an elaborate report on the whole lesson-making situation. The phases of the report adopted by the Lesson Committee- which appeal to the Sunday-school public are: (1) that in the not far distant future the types of Sunday-school lessons to be issued by the Committee shall be two, (a) graded lessons and (b) age-group lessons, i. e., lessons based on the division of the pupils in groups of three years, after the grades now commonly used in public schools. And the Commission was authorized to go ahead and block out such a series for submission at some later date to the Lesson Committee.

The implications of such a move are that the Uniform Lessons will be superseded by either a new age-group series or the graded series already issued, that depending entirely on the school where the change is to be made. This action was taken only after hours of discussion. Even at the shortest space of time the Improved Uniform Series will not be available until the end of 1924, and its continuance beyond that date will depend on the character of the results presented by the Commission, and investigations as to the demands and use made of the kind of lessons now embodied in the Improved Uniform Series.

The Committee is also taking steps looking to meeting the demand for lessons for week-day religious instruction.

\section{Directors of Religious Education}

The annual conference of the Methodist Episcopal Church took action revising the Discipline so as to recognize officially Directors of Religious Education in Churches by adding a section to paragraph 107 of The Discipline: "To elect, where desirable, on nomination of the pastor, a Director of Religious Education, whose duty it shall be, together with the pastor, to have general supervision over the entire educational program of the Church."

\footnotetext{
*Secretary, International Sunday School Lesson Committee.
} 